\title{
Article \\ The Impact of Board Diversity, CEO Characteristics, and Board Committees on Financial Performance in the Case of Romanian Companies
}

\author{
Bogdan Aurelian Mihail ${ }^{1, *}$, Dalina Dumitrescu ${ }^{2}$, Carmen Daniela Micu ${ }^{3}$ and Adriana Lobda ${ }^{3}$ \\ 1 Doctoral School of Finance, Bucharest University of Economic Studies, 6 Piata Romana, \\ 010374 Bucharest, Romania \\ 2 Department of Finance, Bucharest University of Economic Studies, 6 Piata Romana, \\ 010374 Bucharest, Romania; dalina.dumitrescu@fin.ase.ro \\ 3 Department of Masters in Board Practice and Directorship, Henley Business School, University of Reading, \\ Greenlands Campus, Henley-on Thames RG9 3AU, Oxfordshire, UK; carmen.micu@envisia.eu (C.D.M.); \\ adriana.lobda@envisia.eu (A.L.) \\ * Correspondence: bog.mihail@gmail.com
}

check for

updates

Citation: Mihail, Bogdan Aurelian, Dalina Dumitrescu, Carmen Daniela Micu, and Adriana Lobda. 2022. The Impact of Board Diversity, CEO

Characteristics, and Board

Committees on Financial

Performance in the Case of Romanian Companies. Journal of Risk and

Financial Management 15: 7. https:// doi.org/10.3390/jrfm15010007

Academic Editor: Thanasis Stengos

Received: 29 October 2021

Accepted: 20 December 2021

Published: 30 December 2021

Publisher's Note: MDPI stays neutral with regard to jurisdictional claims in published maps and institutional affiliations.

Copyright: (C) 2021 by the authors. Licensee MDPI, Basel, Switzerland. This article is an open access article distributed under the terms and conditions of the Creative Commons Attribution (CC BY) license (https:// creativecommons.org/licenses/by/ $4.0 /)$

\begin{abstract}
This paper examines the impact of board diversity, CEO characteristics, and board committees on the financial performance of the companies listed on the Bucharest Stock Exchange (BSE). In order to test the influence of these characteristics, detailed data on more than 70 firms are collected by hand, for the 2016-2020 period, and comprehensive regression models are estimated. The findings show that there are positive effects of board diversity especially with regard to the independent board members. In terms of the board committees, the audit committee is found to have a favourable influence. The regression coefficients imply that a 10\% increase in the share of independent board members would be associated with a $0.93 \%$ increase in ROE. Based on these findings, it can be argued that improving the corporate governance practices of the companies listed on the BSE would increase the performance and the value of these firms.
\end{abstract}

Keywords: corporate governance; firm performance; board diversity; CEO characteristics; board committees; Romania

\section{Introduction}

Corporate governance has a great influence in determining the efficient management of businesses, with a focus on balancing and reconciling the interests of different stakeholders surrounding companies (Solomon 2020). Depending on the focus and perspective of these stakeholders, the specific dimensions of corporate governance can cover very broad topics and issues. In this context, the board characteristics and board diversity are investigated widely in the corporate governance literature in terms of their effectiveness in the monitoring capacity and in addressing agency problems (Rutherford and Buchholtz 2007; Jermias and Gani 2014). Similarly, some studies examine the effects of certain CEO characteristics such as CEO duality (i.e., CEO holding the position of the Chairperson as well), age, gender, and ethnicity (Manner 2010; Kaplan et al. 2012). Moreover, the literature also examines the effects of board committees such as the audit committee or risk committee. For example, Spira and Bender (2004) argue that "The establishment of board sub-committees has been strongly recommended as a suitable mechanism for improving corporate governance, by delegating specific tasks from the main board to a smaller group and harnessing the contribution of non-executive directors" (p. 489). Hence, committees can become another important corporate governance dimension. In addition to these board and CEO-related characteristics, corporate governance also includes other topics such as minority rights (Ginevri 2011), investor relations (Crifo et al. 2019), executive pay (Sarhan et al. 2019), and corporate social responsibility (Widiatmoko 2020). Within this broad 
context of corporate governance, a major question emerges: "Which provisions, among the many provisions firms have and outside observers follow, are the ones that play a key role in the link between corporate governance and firm value?" (Bebchuk et al. 2009, p. 783). Then, it is possible to focus on different dimensions of corporate governance and their effects on firm performance. The present paper focuses on three main dimensions of corporate governance identified in the literature and examines their effects on the performance of firms on the BSE. These areas are the board diversity (in terms of the shares of the non-executive, independent, women, and foreigner board members), CEO characteristics (e.g., CEO duality, gender, and ethnicity), and board committees. In this way, the paper provides a comprehensive account of the effects of these corporate governance dimensions on firm performance in Romania.

By examining the case of a transition country, i.e., Romania, with an evolving corporate governance structure, this paper contributes to the relevant literature in terms of conducting a comprehensive examination regarding the effects of various corporate governance characteristics on the financial performance of companies listed on the Bucharest Stock Exchange. There are some studies that examine similar topics on the effects of board characteristics and other corporate governance issues such as Vintilă and Gherghina (2013) and Borlea et al. (2017). While these papers provide valuable information on the research topic, the current study aims to conduct a very comprehensive analysis by incorporating many dimensions of corporate governance based on a recent period of time, that is, 2016-2020. Therefore, the present paper greatly expands the existing literature. The results of the paper are also important for policy and managerial purposes in the sense that the findings of the papers (such as the positive performance effects of independent board members and audit committees) produce important policy recommendations-namely, these results indicate that improving corporate governance practices by having independent board members and audit committees would be favourable for the financial performance of companies in the Bucharest Stock Exchange. In return, the favourable performance of the stock market and high standards of corporate governance practices would be important factors supporting the stock market development, financial development, and economic development of the country.

The paper is organised as follows: The next section provides a review of the prior literature and puts the present paper in context. Then, the third section provides the details of the dataset and research methods used in the empirical analysis. The findings are presented in the fourth section, while the fifth section provides a discussion of limitations and future research. Finally, the last section concludes the paper.

\section{Prior Literature}

Corporate governance is a very broad topic that covers many different dimensions of business management and relations among different stakeholders. Becht et al. (2003) state that "Corporate governance is concerned with the resolution of collective action problems among dispersed investors and the reconciliation of conflicts of interest between various corporate claim holders" (p. 1). Hence, corporate governance is interested in the problems that arise from agency relations and collective actions surrounding companies. These issues are examined extensively in the literature in terms of both theoretical approaches and empirical analyses. One of the leading theoretical perspectives informing the corporate governance issues is the agency theory. In terms of agency problems, there can be several stages of agency issues within companies. For example, executives are agents of the shareholders or owners, which are the principal. Then, executives can pursue their own interests at the expense of shareholders, which would create principal-agent problems (Sappington 1991). This type of problem leads to the creation of corporate governance mechanisms that would try to address the agency problems and increase the monitoring capacity of shareholders. In this context, the creation of the board of directors, the presence of independent board members, and the establishment of various board committees, such as audit and risk committees, can be leading corporate governance mechanisms. At another 
level, the firm can be considered as an agent of the society, which would be the principal. Then, in the cases of social and environmental sustainability, the private interest and costs of the companies might conflict with the interests of society and the environment. In this case, another theoretical perspective, i.e., a stakeholder approach would be needed to address such issues surrounding companies. In the stakeholder theory, the firm would not only consider the effects of its actions in terms of profits but would also consider the effects on people and planet, or society and the environment (Freeman and Reed 1983; Freeman 2015). While from a narrow and short-term perspective, the stakeholder approach might look anti-competitive and hurt profitability, given that the social awareness and regulatory expectations on these societal and environmental issues increase, following a stakeholder approach can be favourable for survival, brand image, reputation, and profitability over the long term. Overall, these discussions show that various theoretical approaches such as the agency theory and stakeholder theory can be used to study corporate governance issues. In addition, these theories also produce some testable hypotheses about the relationship of board characteristics (such as independent board members and board diversity), CEO characteristics, and board committees. The relevant hypotheses are examined extensively by empirical studies, as discussed below.

Within the broad context of corporate governance, the present paper focuses on board diversity, board committees, and CEO characteristics. The relevant empirical literature shows that these points can matter for the monitoring effectiveness of boards, as well as the firm value and financial performance (Carter et al. 2003; Adams and Ferreira 2009; Knyazeva et al. 2013; Krause et al. 2014; Kolev et al. 2019). For example, Carter et al. (2003) examine the case of Fortune 1000 companies in terms of women and minority board members. Their empirical results indicate strong positive associations of gender and ethnic diversity with the financial performance of companies. Regarding this positive association, the authors note that board diversity would increase board independence, and in return, board independence would be a positive factor in terms of increasing board monitoring capacity and effectiveness. In their regression models, the authors use Tobin's Q as the dependent variable. In the regression results, board size and CEO duality are found to be negatively associated with firm performance. In addition, the share of internal or executive board members is also negatively related to Tobin's $Q$. Then, the presence of both women and minority members on boards is found to be positively associated with firm performance. Moreover, the variable of the average age of the board members does not have a statistically significant regression coefficient. This paper provides a useful regression framework, which is followed in the present paper as well. In another detailed study, Adams and Ferreira (2009) find that female board members are more active participants in board meetings and audit committees. However, the authors note that mandated quotes on female members can create negative effects on firm value. Knyazeva et al. (2013) to control the issue of endogeneity by using the local labour market conditions of the independent board members as an instrument, confirming their positive effects on firm performance. Overall, this literature shows that board diversity in terms of independent board members has positive effects on firm performance, while the effects of other diversity characteristics are mixed. Based on these findings, the first research hypothesis is postulated as follows:

\section{Hypothesis 1. Independent board members have positive effects on firm performance.}

Another important corporate governance area is the issue of CEO duality, and there is a large body of literature examining this issue. The relevant results are generally mixed. Krause et al. (2014) note that the duality of CEO and Chairperson positions can be examined from different theoretical perspectives such as agency approach, stewardship approach, and managerial power approach. However, these theories do not provide a clear answer on the effects of CEO duality. The empirical studies also produce mixed effects. For example, Baliga et al. (1996) examine 375 companies from Fortune 500 covering the 1980-1991 period and do not find any effects of CEO duality. However, Ballinger and Marcel (2010) examine 
the case of 540 events for the S\&P companies during the 1996-1998 period and find that the negative impacts of interim CEO changes are weakened by CEO duality. In another detailed empirical study, Krause and Semadeni (2013) study the case of 1053 companies from S\&P 1500 and Fortune 1000 and show that the separation of CEO and Chairperson positions have adverse effects after the strong performance but positive impact after the weak performance. Hence, these findings do not find a clear effect of CEO duality on firm performance. Based on these results, the second research hypothesis is stated as follows:

\section{Hypothesis 2. CEO duality has no effects on firm performance.}

The third corporate governance area that the study examines is the board committees. The board of directors is expected to conduct monitoring and supervisory tasks so that the actions of managers are in line with the interests of shareholders (Khan 2011; Pande and Ansari 2014; Alhossini et al. 2021). However, some of these tasks such as risk management, auditing, and remuneration can require more specific expertise. In this context, boards started to for committees to evaluate these dimensions of their companies. For example, Kolev et al. (2019) provide a detailed literature review and conclude that board committees, such as audit committees, can have favourable effects on firm performance. In another recent study, Lee (2020) examines the case of public US companies for the 2005-2015 period and finds that when independent board members are active in board committees, the firm performance measured by ROA improves. Based on this newly developing literature, the third research hypothesis is given as follows:

\section{Hypothesis 3. Audit committees have positive effects on firm performance.}

It needs to be noted that more variables and more research hypotheses can be developed given the extensive nature of the literature on corporate governance. However, in order to have a focused scope, the present study is focused on the above three dimensions on board diversity (specifically independent board members), CEO duality, and board committees (specifically audit committees). In addition, as a transitioning country, Romania has been developing its corporate governance codes in line with the EU and OECD practices. For example, the 2015 Code of Corporate Governance document recommends the majority of the non-executive members be independent (BSE 2015). In addition, it suggests that the committees (such as the audit committee) not be chaired by the Chairperson of the board but by an independent member. Specifically, it states that "The Board should set up an audit committee, and at least one member should be an independent non-executive. The majority of members, including the chairman, should have proven an adequate qualification relevant to the functions and responsibilities of the committee ... The audit committee should be chaired by an independent non-executive member" (BSE 2015, p. 6). Overall, it is seen that Romania is developing important governance codes on the above dimensions. Then, it becomes important to check whether these corporate governance factors produce similar effects in the case of Romania, a transitioning country.

The above topics on board diversity, board committees, and CEO characteristics are also examined in the context of the Bucharest Stock Exchange. For example, Vintilă and Gherghina (2013) examine the effects of board independence and CEO duality. The authors collect firm-level data covering the 2007-2011 period and use Tobin's Q as their dependent variable. Their results indicate that board independence has a negative and non-linear effect in the case of the OLS regression model, whereas there are no statistically significant effects in the case of the fixed-effects regression model. In another study, Vintilă et al. (2015) conduct a more detailed study and find positive effects of board diversity. A more recent study by Borlea et al. (2017) also examines various board characteristics (such as independent board members and audit committees) and their effects on firm performance in the case of Romanian public companies. They note that these specific board characteristics can have positive effects on the financial performance of companies, as they improve the monitoring efficiency of boards and alleviate the corresponding agency problems. The 
authors use data only for 2012 and do not find any statistically significant results. The use of only one year in the sample and the relatively small sample size (i.e., only 55 observations) are possible factors in these weak empirical findings. There are also studies that examine similar topics in the case of central and eastern European (CEE) countries (Primecz et al. 2019). For example, Bistrova and Lace (2011) examine the case of CEE countries in terms of leading corporate governance dimensions, including independent board members and CEO duality, and find that there is a positive association with higher governance scores and better stock market performance. In another study, Firtescu and Terinte (2019) examine the case of firms from 11 CEE countries for the 2004-2013 period using the Orbis dataset and find that "independent internal audit committee ... has a positive sign on firm's profitability" measured by ROE and ROA (p. 114). Hence, these studies on CEE also provide quantitative evidence on the importance of corporate governance. The present paper improves over this relevant literature by conducting a more comprehensive empirical analysis covering the 2016-2020 period for the companies listed on the BSE.

\section{Data and Research Methods}

\subsection{Sample Selection and Variable Description}

The presents study focused on board diversity (the number of non-executives, independents, females, and foreigners), board committees, and CEO characteristics in Romania. The relevant variables are explained in Table 1 . The third column of the table provides some references that use the same variables in their analysis. Regarding the sample selection, data for more than 70 firms in the Bucharest Stock Exchange were collected by hand on these variables - namely, all the firms in the stock market were included in the analysis depending on data available in their annual reports. The sample period covered the last five years of 2016-2020. Hence, the sample size and period coverage are relatively large, to obtain robust findings on the recent corporate governance developments in the Bucharest Stock Exchange.

Table 1. Description of variables.

\begin{tabular}{|c|c|c|}
\hline Variable & Definition & Relevant References \\
\hline Return on equity & $\begin{array}{c}\text { Net profits as a ratio to shareholder } \\
\text { equity }\end{array}$ & Firtescu and Terinte (2019) \\
\hline Return on assets & Net profits as a ratio to total assets & Firtescu and Terinte (2019) \\
\hline Tobin's Q & Market value as a ratio to total asset & Vintilă and Gherghina (2013) \\
\hline Board size & The number of members on the board & Vintilă et al. (2015) \\
\hline Board age & The average age of board members & Ferrero-Ferrero et al. (2015) \\
\hline Firm size & Firm turnover or revenue & Vintilă et al. (2015) \\
\hline Non-executive share & $\begin{array}{l}\text { The number of non-executive members } \\
\text { as a ratio to board size }\end{array}$ & Vintilă et al. (2015) \\
\hline Independent share & $\begin{array}{l}\text { The number of independent members } \\
\text { as a ratio to board size }\end{array}$ & Vintilă et al. (2015) \\
\hline Women share & $\begin{array}{c}\text { The number of women members as a } \\
\text { ratio to board size }\end{array}$ & Vintilă et al. (2015) \\
\hline Foreign share & $\begin{array}{l}\text { The number of foreign members as a } \\
\text { ratio to board size }\end{array}$ & Masulis et al. (2012) \\
\hline Board committees & The number of board committees & Vintilă et al. (2015) \\
\hline Committee members & $\begin{array}{c}\text { The number of members in different } \\
\text { board committees }\end{array}$ & Vintilă et al. (2015) \\
\hline Ceo age & The age of the CEO & Vintilă et al. (2015) \\
\hline CEO duality & $\begin{array}{l}\text { Takes a value of } 1 \text { if the CEO has the } \\
\text { dual duty of CEO and Chairperson }\end{array}$ & Vintilă et al. (2015) \\
\hline
\end{tabular}


Table 1. Cont.

\begin{tabular}{clc}
\hline Variable & \multicolumn{1}{c}{ Definition } & Relevant References \\
\hline CEO women & Takes a value of 1 if women CEO & Vintilă et al. (2015) \\
\hline CEO foreign & Takes a value of 1 if foreign CEO & \\
\hline
\end{tabular}

\subsection{Econometric Specification}

With reference to the research methods, the literature review section showed that regression models are commonly used to examine the effects of different corporate governance dimensions on firm performance. For example, Carter et al. (2003) use a regression model with the dependent variable of Tobin's $Q$ and independent variables of various diversity indicators and CEO characteristics. The present paper also follows a similar regression approach and estimated the following regression model:

$$
\begin{gathered}
R O A_{i t} \text { or } R O E_{i t} \text { or Tobin's } Q_{i t}=\beta_{0}+\beta_{1} \operatorname{Ln}(\text { Firm Size })_{i t}+\beta_{2} \text { BoardSize }_{i t}+ \\
\beta_{3} \text { Board Diversity Measures } i t+\beta_{4} \text { CEO Characteristics } i t+ \\
\beta_{5} \text { Board Committees }_{i t}+\varepsilon_{i, t}
\end{gathered}
$$

In the above regression model, $i$ refers to the company and $t$ refers to the year. The dependent variable was chosen among three performance indicators of ROA or ROE or Tobin's Q. Then, Ln(firm size) and board size were utilised as the main control variables. The regression model also included three sets of independent variables corresponding to the three research hypotheses on the effects of board diversity measures, CEO characteristics, and audit committees. Overall, the paper provides a very rich set of regression models and empirical evidence. In terms of empirical strategy, the pooled OLS methods were utilised. Given the data limitations such as the relatively small number of cross sections (i.e., the number of companies) and low variation on some board characteristics, the panel data methods or dynamic methods were not utilised. These limitations can be addressed in future research as more data points become available.

\section{Findings}

\subsection{Descriptive and Correlation Analyses}

The board age is estimated at 52 years, with a standard deviation of 8 years. With reference to the diversity measures, the share of non-executive board members is $68 \%$, while the share of independent board members is $38 \%$, the share of female board members is $21 \%$, and the share of foreign board members is $18 \%$. Therefore, the lowest levels of board diversity are observed on foreigners and women, while the largest diversity level is observed in the non-executive members.

In terms of CEO characteristics, Table 2 shows that the average CEO age is 53 years, with a standard deviation of 12 years. $30 \%$ of CEOs in the sample hold the Chairperson position as well. In addition, $11 \%$ of CEOs are women and $13 \%$ are foreigners. Hence, the gender and ethnic diversity of CEOs is lower, compared with the board diversity, in both dimensions. Table 2 displays that the average number of committees is 1.66 , with a standard deviation of 1.28. This variable ranges from 0 to 5 in the sample. The recent set of relevant data can be valuable, as there are no studies that examine the effect of board committees and their members on the firm performance of the companies listed on the BSE, to the best knowledge of the authors. In terms of specific board committees, the data collection process was able to recover information on the existence of an audit committee for 40 companies, so that there were 200 observations in five years of the sample. Then, the average member size in the audit committee is estimated as 2.75 , with a standard deviation of 0.78 . In the case of other board committees, the total number of observations is smaller, with 110 observations (i.e., for 22 firms) in the case of remuneration committees and 105 observations (i.e., for 21 firms) in the case of nomination committees. In the case of other board committees, the number of observations is smaller than 5 firms (or 20 observations), thereby making 
statistical analysis infeasible. The last panel of Table 2 presents the summary statistics for the performance indicators. It is found that the average ROA is $3.2 \%$, while the average $\mathrm{ROE}$ is $7.7 \%$ and the average level of Tobin's $\mathrm{Q}$ is 0.677.

Table 2. Summary statistics.

\begin{tabular}{|c|c|c|c|c|c|}
\hline \multicolumn{6}{|c|}{ Descriptive Statistics-Board Characteristics } \\
\hline Variable & Obs & Mean & Std. Dev. & Min & Max \\
\hline Board Size & 345 & 4.971 & 1.73 & 1 & 11 \\
\hline Board Age & 260 & 52.199 & 8.272 & 31.667 & 69.7 \\
\hline Executive Share & 345 & 25.403 & 24.09 & 0 & 100 \\
\hline Non-Executive Share & 345 & 67.585 & 29.602 & 0 & 100 \\
\hline Independent Share & 295 & 38.423 & 30.427 & 0 & 100 \\
\hline Women Share & 340 & 20.466 & 23.14 & 0 & 100 \\
\hline Foreigner Share & 345 & 17.938 & 30.999 & 0 & 100 \\
\hline \multicolumn{6}{|c|}{ Descriptive Statistics-CEO Characteristics } \\
\hline Variable & Obs & Mean & Std. Dev. & Min & Max \\
\hline CEO Age & 245 & 52.531 & 11.465 & 30 & 71 \\
\hline CEO Duality & 320 & 0.297 & 0.458 & 0 & 1 \\
\hline CEO Women & 330 & 0.106 & 0.308 & 0 & 1 \\
\hline CEO Foreign & 360 & 0.125 & 0.331 & 0 & 1 \\
\hline \multicolumn{6}{|c|}{ Descriptive Statistics-Board Committees } \\
\hline Variable & Obs & Mean & Std. Dev. & Min & Max \\
\hline Number of Committees & 305 & 1.656 & 1.277 & 0 & 5 \\
\hline Audit Members & 200 & 2.75 & 0.776 & 1 & 5 \\
\hline Remuneration Members & 110 & 3.136 & 0.818 & 2 & 5 \\
\hline Nomination Members & 105 & 3.048 & 0.955 & 1 & 5 \\
\hline CSR Members & 15 & 4.667 & 0.488 & 4 & 5 \\
\hline Stakeholder Members & 5 & 3 & 0 & 3 & 3 \\
\hline Risk Members & 20 & 3.25 & 0.444 & 3 & 4 \\
\hline \multicolumn{6}{|c|}{ Descriptive Statistics-Firm and Performance Variables } \\
\hline Variable & Obs & Mean & Std. Dev. & Min & Max \\
\hline ROA & 319 & 3.151 & 9.645 & -44.49 & 77.05 \\
\hline ROE & 320 & 7.662 & 14.711 & -52.8 & 86.19 \\
\hline Tobins Q & 119 & 0.677 & 0.664 & 0 & 3.94 \\
\hline Size & 303 & $5.33 \times 10^{8}$ & $1.65 \times 10^{9}$ & 236,000 & $1.48 \times 10^{10}$ \\
\hline ln_Size & 303 & 18.282 & 1.97 & 12.37 & 23.41 \\
\hline
\end{tabular}

Table 3 presents the correlations of the three sets of independent variables (i.e., board diversity measures, $\mathrm{CEO}$ characteristics, and board committees). In the case of the board diversity indicators, only one of the performance indicators, i.e., return on equity (ROE), has statistically significant correlations with some indicators-namely, ROA and Tobin's Q do not display any statistically significant bivariate relationship with the diversity measures. However, in the case of ROE, the shares of both independent and foreign members are positively associated with this performance indicator at the $5 \%$ statistical significance level. In the case of the $\mathrm{CEO}$ characteristics, $\mathrm{ROE}$ is again positively associated with the presence of foreign CEOs. Finally, in the case of board committees, the number of board committees is not correlated with any of the performance indicators in a statistically significant way. However, ROA and Tobin's $Q$ display positive correlations with the number of members in different board committees. Overall, the correlation results in Table 3 provide some initial insights on the possible effects of board diversity in terms of independent and foreign board members and the different committees. Figures 1 and 2 provide some graphical evidence in support of these findings. 
Table 3. Correlation coefficients of firm performance.

\begin{tabular}{|c|c|c|c|c|c|c|c|c|c|}
\hline \multicolumn{10}{|c|}{ Pairwise Correlations with Board Diversity Measures } \\
\hline Variables & (1) & (2) & (3) & (4) & (5) & (6) & (7) & (8) & (9) \\
\hline (1) $\mathrm{ROA}$ & 1.000 & & & & & & & & \\
\hline (2) ROE & $0.405 *$ & 1.000 & & & & & & & \\
\hline (3) Tobin's Q & -0.064 & $0.251 *$ & 1.000 & & & & & & \\
\hline (4) Board Size & $0.140 *$ & 0.055 & 0.097 & 1.000 & & & & & \\
\hline (5) Board Age & 0.025 & -0.024 & -0.030 & $0.135 *$ & 1.000 & & & & \\
\hline (6) Non_exec Share & -0.035 & $-0.13 *$ & 0.079 & $0.261 *$ & $-0.17 *$ & 1.000 & & & \\
\hline (7) Indep Share & -0.100 & 0.053 & 0.181 & -0.039 & $-0.14 *$ & $0.437 *$ & 1.000 & & \\
\hline (8) Women Share & 0.063 & -0.074 & -0.054 & -0.14 * & $-0.15 *$ & $-0.16^{*}$ & $-0.15 *$ & 1.000 & \\
\hline (9) Foreigner Share & -0.20 * & 0.194 * & 0.046 & 0.013 & $-0.24 *$ & 0.124 * & 0.069 & $-0.15^{*}$ & 1.000 \\
\hline \multicolumn{10}{|c|}{ Pairwise Correlations with CEO Characteristics } \\
\hline Variables & (1) & (2) & (3) & (4) & (5) & (6) & (7) & & \\
\hline (1) ROA & 1.000 & & & & & & & & \\
\hline (2) $\mathrm{ROE}$ & $0.405 *$ & 1.000 & & & & & & & \\
\hline (3) Tobin's Q & -0.064 & $0.251 *$ & 1.000 & & & & & & \\
\hline (4) CEO Age & 0.125 & -0.049 & 0.028 & 1.000 & & & & & \\
\hline (5) CEO Duality & 0.023 & -0.011 & -0.040 & $0.487 *$ & 1.000 & & & & \\
\hline (6) CEO Women & -0.034 & -0.043 & 0.084 & -0.104 & $-0.118^{*}$ & 1.000 & & & \\
\hline (7) CEO Foreigner & $-0.192 *$ & 0.111 * & -0.000 & -0.063 & $0.131 *$ & $-0.137^{*}$ & 1.000 & & \\
\hline \multicolumn{10}{|c|}{ Pairwise Correlations with Board Committees } \\
\hline Variables & (1) & (2) & (3) & (4) & (5) & (6) & (7) & & \\
\hline (1) ROA & 1.000 & & & & & & & & \\
\hline (2) ROE & $0.405 *$ & 1.000 & & & & & & & \\
\hline (3) Tobin's Q & -0.064 & 0.251 * & 1.000 & & & & & & \\
\hline (4) Number of Committees & $0.128 *$ & 0.005 & 0.029 & 1.000 & & & & & \\
\hline (5) Audit Member & 0.083 & -0.010 & 0.214 & $0.339 *$ & 1.000 & & & & \\
\hline (6) Remuneration Member & 0.431 * & $0.225^{*}$ & 0.427 * & -0.038 & 0.780 * & 1.000 & & & \\
\hline (7) Nomination Members & 0.263 * & 0.019 & $0.345^{*}$ & -0.057 & 0.691 * & $1.000 *$ & 1.000 & & \\
\hline
\end{tabular}

* shows significance at the 0.05 level.

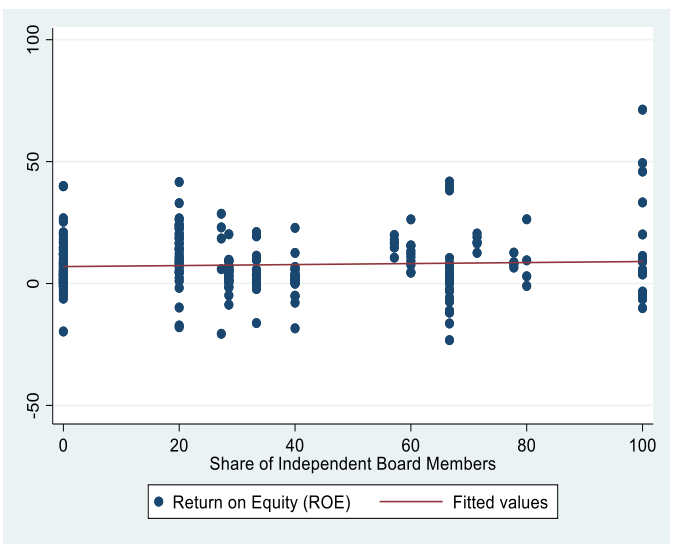

Figure 1. ROE and share of independent members. 


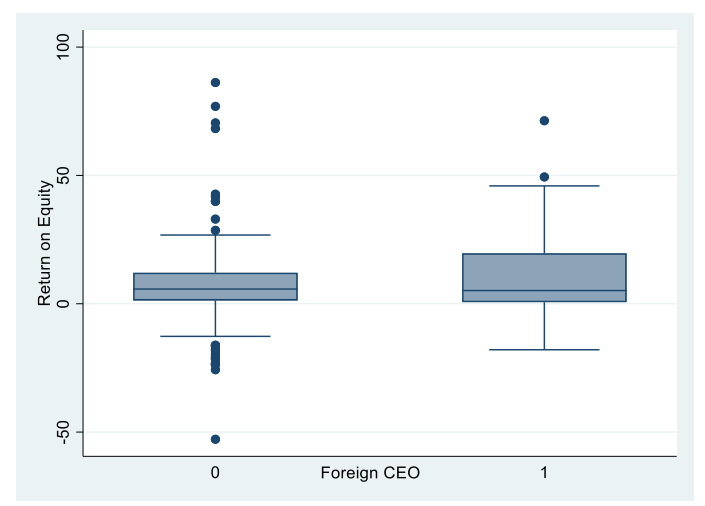

Figure 2. ROE and foreign CEO.

\subsection{Regression Analysis}

This section presents the regression results. Since the number of independent variables is numerous (i.e., there are 14 independent variables in Table 2), including all of them at the same time can lead to large declines in the degrees of freedom in the regression estimations. In order to lessen this problem, the three sets of independent variables were separately included in the regression estimations. Then, a final regression model was estimated with the selected variables from each group.

Results for the board diversity measures in Table 4 are presented in three panels. The upper panel shows the results for the performance variable of ROA, while the middle panel presents the results for ROE and the lower panel for Tobin's Q. In the case of the ROA variable, the firm size has a positive and statistically significant coefficient, thereby indicating that larger firms perform better in this indicator. As additional results, it is found that the share of foreigners on boards is negatively associated with firm performance, whereas the share of women on boards is positively associated. The relevant regression coefficients are statistically significant at the 5\% level. In the case of the middle panel with the performance variable of ROE, it is found that both independent share and foreign share are positively related, with a significance level of 5\%. Finally, in the case of Tobin's Q, the lower panel of Table 4 shows that no regression coefficient is statistically significant at the $10 \%$ level. When the results across these three performance indicators are compared, it is found that the upper panel with ROA has the highest R square value of $14.4 \%$. Overall, these findings provide supportive evidence on the favourable effects of independent board members, thereby supporting the first research hypothesis. This finding is also consistent with the results in the literature about the positive performance effects of independent board members, such as Knyazeva et al. (2013) and Vintilă and Gherghina (2013).

Table 4. OLS regression results with the board diversity measures.

\begin{tabular}{|c|c|c|c|c|c|c|c|}
\hline \multicolumn{8}{|c|}{ Linear Regression for ROA } \\
\hline ROA & Coef. & St. Err. & t-Value & $p$-Value & {$[95 \%$ Conf } & Interval] & Sig \\
\hline ln_size & 1.128 & 0.256 & 4.40 & 0.000 & 0.623 & 1.633 & $* * *$ \\
\hline board_size & 0.330 & 0.360 & 0.92 & 0.360 & -0.379 & 1.040 & \\
\hline non_exec_share & 0.022 & 0.015 & 1.53 & 0.127 & -0.006 & 0.051 & \\
\hline indep_share & -0.019 & 0.022 & -0.87 & 0.387 & -0.061 & 0.024 & \\
\hline women_share & 0.048 & 0.023 & 2.08 & 0.039 & 0.002 & 0.093 & $* *$ \\
\hline foreigner_share & -0.056 & 0.025 & -2.26 & 0.025 & -0.104 & -0.007 & $* *$ \\
\hline Constant & -19.56 & 4.962 & -3.94 & 0.000 & -29.335 & -9.780 & $* * *$ \\
\hline Mean dependent var & \multicolumn{2}{|c|}{3.572} & \multicolumn{2}{|c|}{ SD dependent var } & \multicolumn{2}{|c|}{9.225} & \\
\hline R-squared & \multicolumn{2}{|c|}{0.144} & \multicolumn{2}{|c|}{ Number of obs } & \multicolumn{2}{|c|}{233.000} & \\
\hline F-test & \multicolumn{2}{|c|}{7.047} & \multicolumn{2}{|c|}{ Prob $>F$} & \multicolumn{2}{|c|}{0.000} & \\
\hline Akaike crit. (AIC) & \multicolumn{2}{|c|}{1673.493} & \multicolumn{2}{|c|}{ Bayesian crit. (BIC) } & \multicolumn{2}{|c|}{1697.650} & \\
\hline
\end{tabular}


Table 4. Cont.

\begin{tabular}{|c|c|c|c|c|c|c|c|}
\hline \multicolumn{8}{|c|}{ Linear Regression for ROE } \\
\hline ROE & Coef. & St. Err. & t-Value & $p$-Value & {$[95 \%$ Conf } & Interval] & Sig \\
\hline ln_size & 1.054 & 0.494 & 2.13 & 0.034 & 0.081 & 2.027 & $* *$ \\
\hline board_size & 0.633 & 0.621 & 1.02 & 0.309 & -0.591 & 1.857 & \\
\hline non_exec_share & -0.073 & 0.026 & -2.79 & 0.006 & -0.125 & -0.022 & $* * *$ \\
\hline indep_share & 0.059 & 0.030 & 1.98 & 0.049 & 0.000 & 0.118 & $* *$ \\
\hline women_share & -0.014 & 0.030 & -0.48 & 0.629 & -0.073 & 0.044 & \\
\hline foreigner_share & 0.096 & 0.039 & 2.47 & 0.014 & 0.019 & 0.173 & $* *$ \\
\hline Constant & -13.438 & 8.025 & -1.68 & 0.095 & -29.249 & 2.374 & $*$ \\
\hline Mean dependent var & \multicolumn{2}{|c|}{7.875} & \multicolumn{2}{|c|}{ SD dependent var } & \multicolumn{2}{|c|}{12.232} & \\
\hline R-squared & \multicolumn{2}{|c|}{0.120} & \multicolumn{2}{|c|}{ Number of obs } & \multicolumn{2}{|c|}{236.000} & \\
\hline F-test & \multicolumn{2}{|c|}{4.165} & \multicolumn{2}{|c|}{ Prob $>F$} & \multicolumn{2}{|c|}{0.001} & \\
\hline Akaike crit. (AIC) & \multicolumn{2}{|c|}{1834.358} & \multicolumn{2}{|c|}{ Bayesian crit. (BIC) } & \multicolumn{2}{|c|}{1858.605} & \\
\hline \multicolumn{8}{|c|}{ Linear Regression for Tobin's Q } \\
\hline Tobin's Q & Coef. & St. Err. & t-Value & $p$-Value & {$[95 \%$ Conf } & Interval] & Sig \\
\hline ln_size & 0.048 & 0.031 & 1.57 & 0.120 & -0.013 & 0.110 & \\
\hline board_size & 0.021 & 0.048 & 0.44 & 0.659 & -0.074 & 0.116 & \\
\hline non_exec_share & 0.000 & 0.003 & -0.07 & 0.945 & -0.005 & 0.005 & \\
\hline indep_share & 0.005 & 0.003 & 1.51 & 0.135 & -0.002 & 0.011 & \\
\hline women_share & -0.001 & 0.003 & -0.25 & 0.805 & -0.008 & 0.006 & \\
\hline foreigner_share & 0.000 & 0.004 & 0.09 & 0.928 & -0.007 & 0.007 & \\
\hline Constant & -0.382 & 0.510 & -0.75 & 0.456 & -1.397 & 0.633 & \\
\hline Mean dependent var & \multicolumn{2}{|c|}{0.788} & \multicolumn{2}{|c|}{ SD dependent var } & \multicolumn{2}{|c|}{0.734} & \\
\hline R-squared & \multicolumn{2}{|c|}{0.061} & \multicolumn{2}{|c|}{ Number of obs } & \multicolumn{2}{|c|}{85.000} & \\
\hline F-test & \multicolumn{2}{|c|}{2.043} & \multicolumn{2}{|c|}{ Prob $>$ F } & \multicolumn{2}{|c|}{0.070} & \\
\hline Akaike crit. (AIC) & \multicolumn{2}{|c|}{196.343} & \multicolumn{2}{|c|}{ Bayesian crit. (BIC) } & \multicolumn{2}{|c|}{213.441} & \\
\hline
\end{tabular}

${ }^{* * *} p<0.01,{ }^{* *} p<0.05, * p<0.1$.

Table 5 repeats the same set of regression estimations for the independent variables of CEO characteristics. In the case of the upper panel with the ROA indicator, the size variable is positively associated with this performance measure, whereas having a foreign CEO is negatively associated. In the case of the ROE and Tobin's $Q$ indicators, the results of the middle and lower panels indicate that none of the CEO characteristics is statistically significant at the $10 \%$ level. This is an interesting result, which might arise from the exclusion of important board characteristics in the regression model.

Table 5. OLS regression results with the CEO characteristics.

\begin{tabular}{|c|c|c|c|c|c|c|c|}
\hline \multicolumn{8}{|c|}{ Linear Regression for ROA } \\
\hline ROA & Coef. & St. Err. & t-Value & $p$-Value & {$[95 \%$ Conf } & Interval] & Sig \\
\hline ln_size & 1.063 & 0.312 & 3.40 & 0.001 & 0.448 & 1.679 & $* * *$ \\
\hline board_size & 0.257 & 0.386 & 0.67 & 0.507 & -0.504 & 1.018 & \\
\hline ceo_duality & 1.578 & 1.168 & 1.35 & 0.178 & -0.722 & 3.878 & \\
\hline ceo_women & 0.441 & 1.910 & 0.23 & 0.818 & -3.322 & 4.204 & \\
\hline ceo_foreign & -6.695 & 2.092 & -3.20 & 0.002 & -10.815 & -2.58 & $* * *$ \\
\hline Constant & -17.316 & 6.487 & -2.67 & 0.008 & -30.092 & -4.54 & $* * *$ \\
\hline Mean dependent var & \multicolumn{2}{|c|}{3.304} & \multicolumn{2}{|c|}{ SD dependent var } & \multicolumn{2}{|c|}{9.510} & \\
\hline R-squared & \multicolumn{2}{|c|}{0.116} & \multicolumn{2}{|c|}{ Number of obs } & \multicolumn{2}{|c|}{254.000} & \\
\hline F-test & \multicolumn{2}{|c|}{7.225} & \multicolumn{2}{|c|}{ Prob > F } & \multicolumn{2}{|c|}{0.000} & \\
\hline Akaike crit. (AIC) & \multicolumn{2}{|c|}{1844.753} & \multicolumn{2}{|c|}{ Bayesian crit. (BIC) } & \multicolumn{2}{|c|}{1865.977} & \\
\hline
\end{tabular}


Table 5. Cont.

\begin{tabular}{|c|c|c|c|c|c|c|c|}
\hline \multicolumn{8}{|c|}{ Linear Regression for ROE } \\
\hline ROE & Coef. & St. Err. & t-Value & $p$-Value & {$[95 \%$ Conf } & Interval] & Sig \\
\hline ln_size & 0.775 & 0.646 & 1.20 & 0.231 & -0.496 & 2.046 & \\
\hline board_size & 0.092 & 0.695 & 0.13 & 0.895 & -1.276 & 1.460 & \\
\hline ceo_duality & -0.132 & 1.903 & -0.07 & 0.945 & -3.880 & 3.615 & \\
\hline ceo_women & 0.210 & 2.580 & 0.08 & 0.935 & -4.871 & 5.291 & \\
\hline ceo_foreign & 5.197 & 4.126 & 1.26 & 0.209 & -2.930 & 13.324 & \\
\hline Constant & -7.729 & 11.118 & -0.69 & 0.488 & -29.627 & 14.168 & \\
\hline Mean dependent var & \multicolumn{2}{|c|}{7.743} & \multicolumn{2}{|c|}{ SD dependent var } & \multicolumn{2}{|c|}{14.224} & \\
\hline R-squared & \multicolumn{2}{|c|}{0.025} & \multicolumn{2}{|c|}{ Number of obs } & \multicolumn{2}{|c|}{255.000} & \\
\hline F-test & \multicolumn{2}{|c|}{1.121} & \multicolumn{2}{|c|}{ Prob $>$ F } & \multicolumn{2}{|c|}{0.350} & \\
\hline Akaike crit. (AIC) & \multicolumn{2}{|c|}{2082.180} & \multicolumn{2}{|c|}{ Bayesian crit. (BIC) } & \multicolumn{2}{|c|}{2103.428} & \\
\hline \multicolumn{8}{|c|}{ Linear Regression for Tobin's Q } \\
\hline Tobin's Q & Coef. & St. Err. & t-Value & $p$-Value & {$[95 \%$ Conf } & Interval] & Sig \\
\hline ln_size & 0.028 & 0.040 & 0.69 & 0.491 & -0.052 & 0.108 & \\
\hline board_size & 0.038 & 0.047 & 0.82 & 0.414 & -0.055 & 0.131 & \\
\hline ceo_duality & -0.028 & 0.174 & -0.16 & 0.874 & -0.374 & 0.318 & \\
\hline ceo_women & 0.207 & 0.234 & 0.88 & 0.379 & -0.258 & 0.672 & \\
\hline ceo_foreign & 0.015 & 0.303 & 0.05 & 0.961 & -0.587 & 0.617 & \\
\hline Constant & -0.004 & 0.809 & -0.01 & 0.996 & -1.611 & 1.604 & \\
\hline Mean dependent var & \multicolumn{2}{|c|}{0.719} & \multicolumn{2}{|c|}{ SD dependent var } & \multicolumn{2}{|c|}{0.696} & \\
\hline R-squared & \multicolumn{2}{|c|}{0.027} & \multicolumn{2}{|c|}{ Number of obs } & \multicolumn{2}{|c|}{96.000} & \\
\hline F-test & \multicolumn{2}{|c|}{0.609} & \multicolumn{2}{|c|}{ Prob $>$ F } & \multicolumn{2}{|c|}{0.693} & \\
\hline Akaike crit. (AIC) & \multicolumn{2}{|c|}{211.293} & \multicolumn{2}{|c|}{ Bayesian crit. (BIC) } & \multicolumn{2}{|c|}{226.679} & \\
\hline
\end{tabular}

*** $p<0.01$.

Table 6 presents the OLS regression results for the independent variables related to board committees. The number of committees is included as a relevant variable, along with the number of members in the audit and remuneration committees. Since there were not enough observations in the case of other committees, they were not included in the regression model. The results indicate that the audit committee has a positive and statistically significant effect on firm performance in the case of ROA and ROE, while the remuneration committee has a positive and statistically significant effect In the case of ROA and Tobin's Q. These are novel findings in the literature for the Bucharest Stock Exchange. Overall, the results of Table 6 indicate that having audit committees with enough members would improve the financial performance of companies in Romania. Hence, these findings support the second research hypothesis on the positive performance effects of the audit committees. This favourable effect of audit committees is also consistent with the studies in the literature that find similar positive performance effects, such as Aldamen et al. (2012) and Ghafran and O'Sullivan (2013).

Finally, Table 7 shows the results of the full set of independent variables. To save on the degrees of freedom, the leading variables from the other regression models are included in this table. The upper panel has 196 observations, while this number falls to 61 when the audit and remuneration committee variables are included in the regression equation. In addition, this table is estimated only for the ROE variable. In the upper panel, it is found that the share of independent board members is positively related to the firm performance, whereas CEO duality is negatively related. The regression coefficient of 0.093 for the variable of independent board members implies that a $10 \%$ increase in the share of independent board members would be associated with a $0.93 \%$ increase in ROE. Hence, this effect is economically significant given that the average ROE was $3.2 \%$ in the sample. In the lower panel of Table 7, the results indicate that the audit committee has a positive effect on firm performance. Overall, these results also provide supportive evidence on the 
positive performance effects of independent board members and audit committees, thereby validating both research hypotheses.

Table 6. OLS regression results with board committees.

\begin{tabular}{|c|c|c|c|c|c|c|c|}
\hline \multicolumn{8}{|c|}{ Linear Regression for ROA } \\
\hline ROA & Coef. & St. Err. & t-Value & $p$-Value & {$[95 \%$ Conf } & Interval] & Sig \\
\hline ln_size & 0.403 & 0.308 & 1.31 & 0.195 & -0.212 & 1.019 & \\
\hline number_committees & -0.827 & 0.819 & -1.01 & 0.316 & -2.464 & 0.809 & \\
\hline audit_member & 2.624 & 0.760 & 3.45 & 0.001 & 1.105 & 4.142 & $* * *$ \\
\hline remuneration_members & 1.229 & 0.343 & 3.58 & 0.001 & 0.543 & 1.915 & $* * *$ \\
\hline Constant & -10.386 & 5.073 & -2.05 & 0.045 & -20.526 & -0.247 & $* *$ \\
\hline Mean dependent var & \multicolumn{2}{|c|}{6.373} & \multicolumn{2}{|c|}{ SD dependent var } & \multicolumn{2}{|c|}{5.357} & \\
\hline R-squared & \multicolumn{2}{|c|}{0.415} & \multicolumn{2}{|c|}{ Number of obs } & \multicolumn{2}{|c|}{67.000} & \\
\hline F-test & \multicolumn{2}{|c|}{10.940} & \multicolumn{2}{|c|}{ Prob $>$ F } & \multicolumn{2}{|c|}{0.000} & \\
\hline Akaike crit. (AIC) & \multicolumn{2}{|c|}{388.150} & \multicolumn{2}{|c|}{ Bayesian crit. (BIC) } & \multicolumn{2}{|c|}{399.174} & \\
\hline
\end{tabular}

Linear Regression for ROE

\begin{tabular}{|c|c|c|c|c|c|c|c|}
\hline ROE & Coef. & St. Err. & t-Value & $p$-Value & {$[95 \%$ Conf } & Interval] & Sig \\
\hline ln_size & 1.139 & 0.559 & 2.04 & 0.046 & 0.021 & 2.256 & ** \\
\hline number_committees & -0.520 & 1.389 & -0.38 & 0.709 & -3.297 & 2.256 & \\
\hline audit_member & 3.342 & 0.877 & 3.81 & 0.000 & 1.590 & 5.095 & $* * *$ \\
\hline remuneration_members & 0.161 & 0.561 & 0.29 & 0.775 & -0.960 & 1.281 & \\
\hline Constant & -21.963 & 6.867 & -3.20 & 0.002 & -35.686 & -8.241 & $* * *$ \\
\hline Mean dependent var & \multicolumn{2}{|c|}{8.692} & \multicolumn{2}{|c|}{ SD dependent var } & \multicolumn{2}{|c|}{8.053} & \\
\hline R-squared & \multicolumn{2}{|c|}{0.275} & \multicolumn{2}{|c|}{ Number of obs } & \multicolumn{2}{|c|}{68.000} & \\
\hline F-test & \multicolumn{2}{|c|}{10.403} & \multicolumn{2}{|c|}{ Prob $>$ F } & \multicolumn{2}{|c|}{0.000} & \\
\hline Akaike crit. (AIC) & \multicolumn{2}{|c|}{463.839} & \multicolumn{2}{|c|}{ Bayesian crit. (BIC) } & \multicolumn{2}{|c|}{474.936} & \\
\hline \multicolumn{8}{|c|}{ Linear Regression for Tobin's $Q$} \\
\hline Tobin's Q & Coef. & St. Err. & t-Value & $p$-Value & {$[95 \%$ Conf } & Interval] & Sig \\
\hline ln_size & -0.030 & 0.045 & -0.66 & 0.514 & -0.122 & 0.063 & \\
\hline number_committees & -0.029 & 0.073 & -0.40 & 0.692 & -0.180 & 0.121 & \\
\hline audit_member & 0.056 & 0.127 & 0.44 & 0.663 & -0.205 & 0.316 & \\
\hline remuneration_members & 0.205 & 0.100 & 2.06 & 0.050 & 0.000 & 0.411 & * \\
\hline Constant & 0.673 & 0.731 & 0.92 & 0.366 & -0.832 & 2.179 & \\
\hline Mean dependent var & \multicolumn{2}{|c|}{0.809} & \multicolumn{2}{|c|}{ SD dependent var } & \multicolumn{2}{|c|}{0.434} & \\
\hline R-squared & \multicolumn{2}{|c|}{0.215} & \multicolumn{2}{|c|}{ Number of obs } & \multicolumn{2}{|c|}{30.000} & \\
\hline F-test & \multicolumn{2}{|c|}{2.131} & \multicolumn{2}{|c|}{ Prob $>$ F } & \multicolumn{2}{|c|}{0.107} & \\
\hline Akaike crit. (AIC) & \multicolumn{2}{|c|}{36.767} & \multicolumn{2}{|c|}{ Bayesian crit. (BIC) } & \multicolumn{2}{|c|}{43.773} & \\
\hline
\end{tabular}

*** $p<0.01,{ }^{* *} p<0.05,{ }^{*} p<0.1$.

The above findings are closely related to the theoretical and empirical studies in the literature. The favourable impacts of having independent members on boards and establishing audit committees are consistent with the agency theory and the resource-based view of the firm (Lockett et al. 2009; Panda and Leepsa 2017; Raimo et al. 2021). In addition, the positive effects of independent board members and audit committees in the case of Romania are consistent with the relevant literature that finds similar positive effects of both variables in other countries and Romania (Knyazeva et al. 2013; Vintilă and Gherghina 2013). Similar findings on the effects of board independence and audit committees are also shown in the case of CEE countries by Bistrova and Lace (2011) and Firtescu and Terinte (2019). Hence, the results of the present paper provide supportive evidence about the importance of various corporate governance indicators in the case of Romania. 
Table 7. OLS regression results with full set of independent variables.

\begin{tabular}{|c|c|c|c|c|c|c|c|}
\hline \multicolumn{8}{|c|}{ Linear Regression for ROE } \\
\hline ROE & Coef. & St. Err. & t-Value & $p$-Value & {$[95 \%$ Conf } & Interval] & Sig \\
\hline ln_size & 0.857 & 0.609 & 1.41 & 0.161 & -0.345 & 2.059 & \\
\hline board_size & 1.223 & 0.826 & 1.48 & 0.140 & -0.406 & 2.853 & \\
\hline non_exec_share & -0.170 & 0.059 & -2.86 & 0.005 & -0.287 & -0.053 & $* * *$ \\
\hline indep_share & 0.093 & 0.048 & 1.96 & 0.052 & -0.001 & 0.188 & $*$ \\
\hline women_share & 0.003 & 0.043 & 0.07 & 0.947 & -0.082 & 0.088 & \\
\hline foreigner_share & 0.031 & 0.049 & 0.65 & 0.519 & -0.064 & 0.127 & \\
\hline ceo_duality & -4.661 & 2.776 & -1.68 & 0.095 & -10.138 & 0.816 & * \\
\hline ceo_women & -1.659 & 2.690 & -0.62 & 0.538 & -6.966 & 3.648 & \\
\hline ceo_foreign & 0.891 & 5.678 & 0.16 & 0.875 & -10.311 & 12.094 & \\
\hline number_committees & -1.589 & 1.018 & -1.56 & 0.120 & -3.599 & 0.420 & \\
\hline Constant & -1.584 & 10.595 & -0.15 & 0.881 & -22.487 & 19.318 & \\
\hline Mean dependent var & \multicolumn{2}{|c|}{8.339} & \multicolumn{2}{|c|}{ SD dependent var } & \multicolumn{2}{|c|}{12.260} & \\
\hline R-squared & \multicolumn{2}{|c|}{0.105} & \multicolumn{2}{|c|}{ Number of obs } & \multicolumn{2}{|c|}{196.000} & \\
\hline F-test & \multicolumn{2}{|c|}{1.744} & \multicolumn{2}{|c|}{ Prob $>$ F } & \multicolumn{2}{|c|}{0.074} & \\
\hline Akaike crit. (AIC) & \multicolumn{2}{|c|}{1538.018} & \multicolumn{2}{|c|}{ Bayesian crit. (BIC) } & \multicolumn{2}{|c|}{1574.077} & \\
\hline
\end{tabular}

\begin{tabular}{|c|c|c|c|c|c|c|c|}
\hline \multicolumn{8}{|c|}{ Linear Regression for ROE } \\
\hline ROE & Coef. & St. Err. & t-Value & $p$-Value & {$[95 \%$ Conf } & Interval] & Sig \\
\hline ln_size & -0.386 & 0.766 & -0.50 & 0.617 & -1.925 & 1.153 & \\
\hline board_size & -0.481 & 0.857 & -0.56 & 0.577 & -2.204 & 1.241 & \\
\hline non_exec_share & 0.122 & 0.087 & 1.41 & 0.166 & -0.053 & 0.297 & \\
\hline indep_share & -0.048 & 0.065 & -0.75 & 0.457 & -0.178 & 0.081 & \\
\hline women_share & -0.049 & 0.102 & -0.48 & 0.633 & -0.254 & 0.156 & \\
\hline foreigner_share & 0.229 & 0.130 & 1.77 & 0.084 & -0.032 & 0.490 & * \\
\hline ceo_duality & -0.413 & 2.640 & -0.16 & 0.876 & -5.722 & 4.896 & \\
\hline ceo_women & -4.922 & 2.707 & -1.82 & 0.075 & -10.364 & 0.520 & * \\
\hline ceo_foreign & -6.773 & 9.209 & -0.74 & 0.466 & -25.289 & 11.742 & \\
\hline number_committees & 1.518 & 1.516 & 1.00 & 0.322 & -1.530 & 4.567 & \\
\hline audit_member & 2.713 & 1.155 & 2.35 & 0.023 & 0.390 & 5.036 & $* *$ \\
\hline remuneration_members & 0.126 & 1.600 & 0.08 & 0.938 & -3.092 & 3.343 & \\
\hline Constant & -1.134 & 17.627 & -0.06 & 0.949 & -36.576 & 34.308 & \\
\hline Mean dependent var & \multicolumn{2}{|c|}{8.898} & \multicolumn{2}{|c|}{ SD dependent var } & \multicolumn{2}{|c|}{8.466} & \\
\hline R-squared & \multicolumn{2}{|c|}{0.351} & \multicolumn{2}{|c|}{ Number of obs } & \multicolumn{2}{|c|}{61.000} & \\
\hline F-test & \multicolumn{2}{|c|}{12.793} & \multicolumn{2}{|c|}{ Prob > F } & \multicolumn{2}{|c|}{0.000} & \\
\hline Akaike crit. (AIC) & \multicolumn{2}{|c|}{432.325} & \multicolumn{2}{|c|}{ Bayesian crit. (BIC) } & \multicolumn{2}{|c|}{459.766} & \\
\hline
\end{tabular}

${ }^{* * *} p<0.01,{ }^{* *} p<0.05,{ }^{*} p<0.1$.

The findings of the present paper have also important managerial and policy implications. Regarding corporations, the implementation of best corporate governance practices such as the employment of independent board members and the establishment of audit committees. The shareholders can strive to implement these policies, as they would greatly benefit from these corporate governance indicators in the case of independent board members and audit committees. However, in the case of CEO duality, there is no robust evidence in terms of negative or positive effects. This finding is also consistent with the results in the literature. From a broad perspective, the results indicate that improving corporate governance practices in the Bucharest Stock Exchange would create positive performance effects for public companies. Hence, the 2015 Code of Corporate Governance by BSE makes useful suggestions about independent board members and audit committees. These recommendations can be strengthened and some specific corporate governance strategies can be made mandatory based on the findings of the present study. In return, higher performance would increase investor attention and inflows, thereby supporting stock market development, financial development, and economic development in the country. 


\section{Limitations and Future Research}

This paper utilises a unique and valuable dataset on the joint-stock companies in Romania to see the possible effects of three corporate governance dimensions (board diversity in terms of independent board members, CEO duality, and audit committees) on financial performance. The paper also produces important quantitative results on the importance of corporate governance for Romania. Hence, it contributes to the relevant literature with evidence from a transitioning country. However, the study also suffers from some limitations that can be addressed in future research. As the data were collected by hand, the number of years and the number of control/independent variables were restricted to some extent. Expanding these dimensions would lead to a larger sample size, as well as more control variables such as liquidity and leverage that can affect firm performance. Moreover, stock performance indicators can also be used as additional dependent variables. Future research can make effort to address these data issues by collecting larger datasets on more variables. In addition to these data limitations, the use of only pooled OLS methods stands out as a methodological limitation. Normally, the data have a panel data nature, which would allow the implementation of various panel data methods, such as fixed effects and dynamic GMM estimations. However, the cross-sectional dimension in the dataset is relatively small, and there is not much variation in the board characteristics of the sample companies. Therefore, it is difficult to obtain strong results in the present sample with other estimation methods. This limitation also restricts the analysis in terms of addressing endogeneity issues. These methodological limitations can also be addressed in future research by using more data years and information on more board characteristics. Another possible extension in future research can be to conduct a cross-country analysis with other transition countries in the same region, in order to investigate if the findings from Romania could be generalised to them.

\section{Conclusions}

This paper examined the impact of board diversity, CEO characteristics, and board committees on the financial performance of the companies listed on the Bucharest Stock Exchange. The relevant literature on these corporate governance dimensions highlights the finding that board diversity and committees can play important roles in terms of increasing the effectiveness of board monitoring and improving firm value. In addition, the CEO duality might have negative effects on firm performance, as it can restrict the ability of the board to monitor and supervise the activities of executives. In order to test the relevance of these arguments for the case of the companies listed on the BSE, detailed data were collected by hand on these indicators for more than 70 firms covering the 2016-2020 period. Then, descriptive, correlation, and regression analyses were conducted to document the possible effects of board diversity, CEO characteristics, and board committees. The relevant results indicate that there are positive effects of board diversity in terms of independent members on boards. Regarding board committees, the audit committee is found to have positive performance effects. In terms of quantitative sizes, the regression coefficient of 0.093 for the independent board members in the case of the dependent variable of ROE implies that a $10 \%$ increase in the share of independent board members would be associated with a $0.93 \%$ increase in ROE. In conclusion, the economic effects of the empirical findings are also significant. Based on these findings, it can be argued that improving the corporate governance practices of the companies listed on the BSE would improve the valuation and performance of these firms. There are some research limitations in the present study that can be addressed in future research. The empirical analysis relies on the OLS regression models, while future research can implement more advanced regression methods such as panel data regressions and IV/GMM regressions (Wooldridge 2010). In addition, the dataset can be further improved by incorporating additional firm and board variables, as well as extending the sample period to earlier years. 
Author Contributions: Conceptualization, B.A.M. and D.D.; data curation, B.A.M., C.D.M. and A.L.; Formal analysis, B.A.M., D.D. and C.D.M.; Methodology, B.A.M., C.D.M. and A.L.; Resources, C.D.M. and A.L. All authors have read and agreed to the published version of the manuscript.

Funding: This research received no external funding.

Institutional Review Board Statement: Not applicable.

Informed Consent Statement: Not applicable.

Data Availability Statement: Not applicable.

Conflicts of Interest: The authors declare no conflict of interest.

\section{References}

Adams, Renée B., and Daniel Ferreira. 2009. Women in boardroom and their impact on governance and performance. Journal af Financial Economics 94: 291-309. [CrossRef]

Aldamen, Husam, Keith Duncan, Simone Kelly, Ray McNamara, and Stephan Nagel. 2012. Audit committee characteristics and firm performance during the global financial crisis. Accounting $\mathcal{E}$ Finance 52: 971-1000.

Alhossini, Mohammed A., Collins G. Ntim, and Alaa Mansour Zalata. 2021. Corporate board committees and corporate outcomes: An international systematic literature review and agenda for future research. The International Journal of Accounting 56: 2150001. [CrossRef]

Baliga, Baliga, B. Ram, R. Charles Moyer, and Ramesh S. Rao. 1996. CEO duality and firm performance: What's the fuss? Strategic Management Journal 17: 41-53. [CrossRef]

Ballinger, Gary A., and Jeremy J. Marcel. 2010. The use of an interim CEO during succession episodes and firm performance. Strategic Management Journal 31: 262-83. [CrossRef]

Bebchuk, Lucian, Alma Cohen, and Allen Ferrell. 2009. What matters in corporate governance? The Review of Financial Studies 22: 783-827. [CrossRef]

Becht, Marco, Patrick Bolton, and Ailsa Röell. 2003. Corporate governance and control. In Handbook of the Economics of Finance. Amsterdam: S.l.: Elsevier, pp. 1-109.

Bistrova, Julia, and Natalja Lace. 2011. Evaluation of corporate governance influence on stock performance of CEE companies. WMSCI 2011 Proceedings I, United States of America, Orlando 19: 59-64.

Borlea, Nicolae, Monica Violeta Achim, and Codruța Mare. 2017. Board characteristics and firm performances in emering economies. Lessons from Romania. Economic Research-Ekonomska Istrazivanja 30: 55-75. [CrossRef]

Bucharest Stock Exchange (BSE). 2015. Code of Corporate Governance. Available online: https://www.bvb.ro/info/Rapoarte/ Diverse/ENG_Corporate\%20Governance\%20Code_WEB_revised.pdf (accessed on 5 March 2021).

Carter, David A., Betty J. Simkins, and W. Gary Simpson. 2003. Corporate governance, board diversity and firm value. Financial Review 38: 33-53. [CrossRef]

Crifo, Patricia, Elena Escrig-Olmedo, and Nicolas Mottis. 2019. Corporate governnce as akey driver of corporate sustainability in France: The role of board members and investor relations. Journal of Business Ethics 159: 1127-46. [CrossRef]

Ferrero-Ferrero, Idoya, M. Ángeles Fernández-Izquierdo, and M. Jesús Muñoz-Torres. 2015. Age diversity: An empirical study in the board of directors. Cybernetics and Systems 46: 249-70. [CrossRef]

Firtescu, Bogdan, and Paula Terinte. 2019. Effects of Internal Audit on Firm Profitability. Evidence from CEE Countries. Annals of Faculty of Economics 1: 114-27.

Freeman, R. Edward. 2015. Stakeholder theory. In Wiley Encyclopedia of Management. Chichester: Wiley, pp. 1-6.

Freeman, R. Edward, and David L. Reed. 1983. Stockholders and stakeholders: A new perspective on corporate governance. California Management Review 25: 88-106. [CrossRef]

Ghafran, Chaudhry, and Noel O'Sullivan. 2013. The governance role of audit committees: Reviewing a decade of evidence. International Journal of Management Reviews 15: 381-407. [CrossRef]

Ginevri, Andrea Sacco. 2011. The rise of long-term minority shareholders' rights in publicly held corporations and its effect on corporate governance. European Business Organization Law Review 12: 587-618. [CrossRef]

Jermias, Johnny, and Lindawati Gani. 2014. The impact of board capital and board characteristics on firm performance. The British Accounting Review 46: 135-53. [CrossRef]

Kaplan, Steven N., Mark M. Klebanov, and Morten Sorensen. 2012. Which CEO characteristics and abilities matter? The Journal of Finance 67: 973-1007. [CrossRef]

Khan, Humera. 2011. A literature review of corporate governance. In International Conference on E-Business, Management and Economics. Singapore: IACSIT Press, vol. 25, pp. 1-5.

Knyazeva, Anzhela, Diana Knyazeva, and Ronald W. Masulis. 2013. The supply of corporate directors and board independence. The Review of Financial Studies 26: 1561-605. [CrossRef]

Kolev, D. Kalin, David B. Wangrow, Vincent L. Barker, II, and Donald J. Schepker. 2019. Board committees in corporate governance: A cross-disciplinary review and agenda for the future. Journal of Management Studies 56: 1138-93. [CrossRef] 
Krause, Ryan, and Matthew Semadeni. 2013. Apprentice, departure, and demotion: An examination of the three types of CEO-board chair separation. Academy of Management Journal 56: 805-26. [CrossRef]

Krause, Ryan, Matthew Semadeni, and Albert A. Cannella Jr. 2014. CEO duality: A review and research agenda. Journal of Management 40: 256-86. [CrossRef]

Lee, Wei-Ming. 2020. The determinants and effects of board committees. Journal of Corporate Finance 65: 101747. [CrossRef]

Lockett, Andy, Steve Thompson, and Uta Morgenstern. 2009. The development of the resource-based view of the firm: A critical appraisal. International Journal of Management Reviews 11: 9-28. [CrossRef]

Manner, Mikko H. 2010. The impact of CEO characteristics on corporate social performance. Journal of Business Ethics 93: 53-72. [CrossRef]

Masulis, Ronald W., Cong Wang, and Fei Xie. 2012. Globalizing the boardroom-The effects of foreign directors on corporate governance and firm performance. Journal of Accounting and Economics 53: 527-54. [CrossRef]

Panda, Brahmadev, and N. M. Leepsa. 2017. Agency theory: Review of theory and evidence on problems and perspectives. Indian Journal of Corporate Governance 10: 74-95. [CrossRef]

Pande, Santosh, and Valeed Ahmad Ansari. 2014. A theoretical framework for corporate governance. Indian Journal of Corporate Governance 7: 56-72.

Primecz, Henriett, Daniel Havran, and Zsolt Lakatos. 2019. How Does Female Presence on the Management and Supervisory Boards Impact the Performance in CEE? In Academy of Management Proceedings. Briarcliff Manor: Academy of Management, vol. 2019, p. 10602.

Raimo, Nicola, Filippo Vitolla, Arcangelo Marrone, and Michele Rubino. 2021. Do audit committee attributes influence integrated reporting quality? An agency theory viewpoint. Business Strategy and the Environment 30: 522-34. [CrossRef]

Rutherford, Matthew A., and Ann K. Buchholtz. 2007. Investigating the relationship between board characteristics and board information. Corporate Governance: An International Review 15: 576-84. [CrossRef]

Sappington, David E. M. 1991. Incentives in principal-agent relationships. Jounal of Economic Perspectives 5: 45-66. [CrossRef]

Sarhan, Ahmed A., Collins G. Ntim, and Basil Al-Najjar. 2019. Board diversity, corporate governance, corporate performance and executive pay. International Journal of Finance E Economics 24: 761-86.

Solomon, Jill. 2020. Corporate Governance and Accountability, 5th ed.Hoboken: Wiley.

Spira, Laura F., and Ruth Bender. 2004. Compare and contrast: Perspectives on board committees. Corporate Governance: An International Review 12: 489-99. [CrossRef]

Vintilă, Georgeta, and Stefan Cristian Gherghina. 2013. Board of directors independence and firm value: Empirical evidence based on thr Bucharest stock exchange listed companies. International Journal of Economics and Financial Issues 3: 885.

Vintilă, Georgeta, Mihaela Onofrei, and Ştefan Cristian Gherghina. 2015. The effects of corporate board and CEO characteristics on firm value: Empirical evidence from listed companies on the Bucharest stock exchange. Emerging Markets Finance and Trade 51: 1244-60. [CrossRef]

Widiatmoko, Jacobus. 2020. Corporate Governance Mechanism and Corporate Social Responsability on Firm Value. Relevance: Journal of Management and Business 3: 13-25. [CrossRef]

Wooldridge, Jeffrey M. 2010. Econometric Analysis of Cross Section and Panel Data. Cambridge: S.l.: MIT press. 